\title{
An Exemplary Legal Battle against Union Discrimination at the Peugeot-Sochaux Plant (1995-2000)
}

\section{Nicolas Hatzfeld}

Translator. Patricia Finn

\section{(2) OpenEdition}

\section{Journals}

\section{Electronic version}

URL: http://journals.openedition.org/travailemploi/7618

DOI: 10.4000/travailemploi.7618

ISSN: 1775-416X

\section{Publisher}

DARES - Ministère du Travail

\section{Printed version}

Date of publication: 30 December 2017

Number of pages: $31-54$

ISSN: 0224-4365

\section{Electronic reference}

Nicolas Hatzfeld, "An Exemplary Legal Battle against Union Discrimination at the Peugeot-Sochaux Plant (1995-2000)", Travail et Emploi [Online], Hors-série | 2017, Online since 11 July 2019, connection on 13 April 2021. URL: http://journals.openedition.org/travailemploi/7618 ; DOI: https://doi.org/ 10.4000/travailemploi.7618 


\title{
An Exemplary Legal Battle against Union Discrimination at the Peugeot-Sochaux Plant $(1995-2000)^{*}$
}

\author{
Nicolas Hatzfeld**
}

\begin{abstract}
The end of the 1990s will be remembered for the protracted legal battle between blue-collar CGT (Confédération générale du travail-General Confederation of Labour) union members and the management of the Peugeot-Sochaux car assembly site (PSA group). A group of CGT-affiliated skilled workers wishing to expose a history of discrimination against trade union members finally decided to take legal action against the PSA management. Assisted by legal experts and lawyers dedicated to their cause, and after a series of initial legal proceedings via the usual channels, the scope and jurisdiction of the initial claim was extended and the group succeeded in proving the existence of systemic intentional discrimination towards union members. Not only would this successful outcome put an end to a policy of trade union repression spanning over three decades, it also threw fresh light on the relation between career advancement (or lack thereof) and union activity at local union level. Finally, this victory would serve as a model across the union movement as a whole.
\end{abstract}

\footnotetext{
t the end of the 1990s CGT labour activists at the PSA plant filed a series of comAplaints against their employers for discrimination, the aim being to prove, stop and obtain compensation for discriminatory practices spanning several decades. Even if this type of initiative was nothing new, on this occasion the different judges ruled in the union's favour, obliging the PSA management to modify their usual uncompromising stance and, for a change, negotiate and bargain with employees. Compensation was awarded for accumulated loss of wages and deliberate obstruction to career development. As regards this latter point, career advancement, which had remained static for

* Translation: Patricia Finn.

Article published in French in Travail et Emploi, no 145, janvier-mars 2016.

** University of Évry Val d'Essonne, Institutions et dynamiques historiques de l'économie et de la société (IDHES); nicolas.hatzfeld@univ-evry.fr.
} 
years -without any apparent grounds- was subsequently reviewed. This unprecedented result sent shock waves throughout PSA and in the region. Suddenly, the company, up to then a key employer and a major provider of local employment, lost its foothold. On the national level, both management and union representatives at PSA -for years the largest manufacturer in France- were seriously destabilised. In effect, the PSA management was notorious for its carefully crafted social policy, both unyielding and non-negotiable. Even if it did have to contend with deep-rooted union power on the shop floor and at the regional level, it made no secret of its iron-fist policy when it came to managing industrial relations. Up to this point, the legal option had always worked in PSA's favour, whereas the labour administration would only rarely intervene.

It is thus through the lens of this battle of wills that the success of this union resistance movement will be examined. The fact that PSA, one of the most powerful companies in France, made major concessions even before the legal proceedings came to a close, showed that the union approach was both innovative and appropriate in its interpretation of labour law and workers' rights. The Peugeot trade union victory thus served as a model and generated a flood of claims filed before the courts (CLERC, 2004; CHAPPE, 2013; HATZFELD, 2014 ${ }^{1}$ ). It led to the creation of a new jurisprudence, which by extension changed the conditions of trade union activity in both medium sized and large French companies. Yet, the legal actions launched by the Sochaux branch of the CGT did not reflect totally new or exceptional situations: indeed both the press and other media had already reported incidences of repression against the CGT or CFDT (Confédération française démocratique du travail - French Democratic Confederation of Labour) union members. The key success factor of the Sochaux cases was both the quality and abundance of the evidence provided, and the fact that they stood up to the challenges of this previously unexplored legal area -from a legal standpoint in any case- namely, discrimination. Up to then, union resistance had portrayed repressed activists as working-class heroes spearheading the workers' struggle and, more broadly, that of all company employees. By using this symbolic representation they could demonstrate that the management targeted the power of collective action. In effect, the union representatives put their own situation aside in the interest of collective empowerment. Above and beyond the administrative and legal aspects, the defence of workers' rights by the official union representative was supposed to reinforce the ability of the workers to defend their collective rights. In the case we are referring to here, the new direction taken to fight discrimination led to a certain repositioning. On the one hand, it targeted repression, a tactic used to regulate industrial relations and their conflictual aspects. On yet another level, discrimination affected individuals in the workplace, their professional worth and the quality of their work. More importantly, discrimination also affected the wage relation (and relating key issues), while at the same time highlighting the factors that skew or falsify this relationship.

1. See also, «La portée des victoires sur les discriminations syndicales », Le Droit ouvrier, documents used for the CGT Confederal Day and published on 16 June 2005. 
This paper will document the legal challenges faced by a small group of labour activists who launched the initial procedures. Thus, the angle of approach taken will be the issue of discrimination as it is interpreted by the courts of law, using two types of evidence. On one level, discriminatory treatment by the company towards workers, be it their career, their work or other aspects of the wage relation and on another level, the undeniable link between this unfavourable treatment and the different types of involvement in the CGT and CFDT trade unions. The text will start with a detailed account of the legal proceedings. This will place them in the context of industrial relations, thereby identifying the changes they brought about and their impact. However, as the story unfolds it a second dimension will emerge. In effect, the first phase was intended -in the interest of efficacy from a legal point of view- to showcase those cases most likely to prove the existence of discrimination. However, the second phase focused on the extent and scope of this phenomenon and its systemic nature. Before concluding, we shall examine historical events, which in the course of previous decades were building up and leading up to this system -a system driven by a deliberate policy of repression.

\section{Complementary Legal Procedures}

In 1994, three CGT militants working at the Peugeot-Sochaux tool shop reached out to a confederal legal advisor called Pascal Moussy. They wished to discuss the possibility of engaging legal proceedings against their employer on the grounds of discrimination against themselves and their fellow union members -discrimination affecting their work, their wage and their career development. ${ }^{2}$

For the CGT and the CFDT alike, this was nothing new. The struggle against trade union repression was a familiar and recurrent issue: discriminatory practices had been recorded since 1981 in the same workshop. The CGT representative, who had intervened during that time, therefore forwarded the local work inspector a list of union members who had been "penalised in terms of remuneration and promotion". An ensuing enquiry concluded that without a doubt "discrepancies in promotion and remuneration among staff representatives, among militant and non-militant employees" did indeed exist. He then contacted the site management and requested that "logical adjustments be made."3 Management's response was simply to up the grade of some of the militants concerned. Some years later, another union representative in the sector

2. This text is mostly based on documentary sources and archives: the case compiled by Pascal Moussy, Un cas didactique : l'affaire Peugeot, published by LDAJ-CGT in February 1999; François Clerc's personal file; the factual documents compiled by Tiennot Grumbach for the correctional hearing on September 1998. This text mostly leaves out a lot of verbal material, especially dozens of interviews by the author with current or former Peugeot employees who talked about union repression: these interviews took place in 1983, 1996-1998 and 2004-2005.

3. M. Boillot, work inspector in Montbéliard, Lettre à M. Christian Viénot, délégué du personnel, 15 April1982.

Tiennot Grumbach collection. 
reached out to another labour inspector from Montbéliard concerning cases of union activity-related discrimination impacting wages. Following the site management's promise to look into the issue, the labour inspector offered to show the union members "the method used and to compile any possible criticism of the latter." ${ }^{\text {N }}$ Nothing noteworthy resulted from this initiative and the situation remained unchanged. It was further compounded in 1988 when the Cour de Cassation (Supreme Court) threw out the Peugeot sentence (awarded in first instance and upheld in appeal) for incidents of discriminatory action against union members observed on another site: this decision would inevitably entrench the company in its practices.

On the shop floor at the beginning of the 1990s, the three activists mentioned above persevered in their efforts to prevent management from obstructing their natural career advancement. One of them had his colleagues sign a petition supporting his case. At the same time, the second was subjected to continuing harassment from his superiors. As for the third, he obtained his baccalauréat ${ }^{5}$ in 1992 and requested a position commiserate with his new academic qualification. He was given to understand -in an informal manner- that his CGT union membership was an impediment to his promotion. This refusal clinched the matter. The three workers decided to launch proceedings, long and risky perhaps, but potentially a means of having union discrimination acknowledged, thereby bringing about a change to these practices. Then the trio and their legal advisor Pascal Moussy started preparing a request for a summary court judgement before the Paris Labour Tribunal -a procedure applied to urgent cases or clearly illicit activities (this however still needed to be proved). Results being the priority, Moussy and his team decided to "cherry-pick" the cases to be presented, in other words, choose those most likely to produce irrefutable proof of discrimination and prove solid enough to stand up to the many legal challenges to come. After six months' procedural wrangling won in appeal by the union members, the President of the Court of First Instance of the Paris Labour Tribunal examined the case on 4 June 1996. He observed the existence of union discrimination against the six employee plaintiffs and sentenced Peugeot to pay a provision for compensation for damages. In a noteworthy comment, Jean-Maurice Verdier (1996), professor of law, pointed out the importance of this judgement and deemed it groundbreaking from several standpoints. He also pointed out that the judge had carefully examined each of the cases presented and that the cases presented by the workers were backed up by solid evidence. Peugeot lost their appeals on 19 July 1996 and 21 February 1997. The company then took the case to the Cour de Cassation.

As early as the first summary judgement, the press considered PSA was losing. The Sochaux CGT Union branch, which up to then had acted as an observer, became actively involved following this first successful outcome and a large number of their militants reached agreement concerning launching future action. It was not so easy to reach consensus as to the approach to be adopted, however. The minority group that

4. M. Beccucci, deputy work director in Montbéliard, Lettre à M. François Clerc, délégué du personnel, 15 September 1986.Tiennot Grumbach collection, Appendix IV, G15.

5. The baccalauréat is a national examination partially comparable to the A-level. 
had formed around the core of workers who initially launched the process were all for continuing the legal battle to obtain a clearly stated sentence and compensation for Peugeot's discriminatory policy against the union members. However a majority of militants supported the idea of opening negotiations with management on this issue. A document was drafted in this respect and sent to the PSA management in October 1996. In this it was suggested that union members' careers should henceforth be jointly monitored. As for the victims of discrimination, they should receive compensation based on "alignment criteria" to be agreed on. But the PSA management were entrenched in their position; they refused to negotiate and hid behind the legal argument. The original team that had launched the first procedure then decided to lodge a new complaint, this time for a second group of union members. It tried unsuccessfully to bring in the CFDT, which despite showing initial interest, chose to back out of this legal struggle. 18 new case files were prepared and once their contents were deemed sufficiently solid, were duly submitted to the Paris Labour Tribunal. The same procedure produced the same results -PSA unsuccessfully appealed the decision and were sentenced by the Paris Labour Tribunal. The Appeal Court then confirmed the verdict on 13 June 1997 and 14 January 1998.

At the same time, criminal proceedings were initiated. Although they were complementary to the previous ones, they stood out in certain respects. They were a result of an initiative taken by the labour inspector who discovered the file left by his predecessors when he took up his post in Montbéliard. Aware of the need to tread cautiously when it came to such a sensitive case, he met with union members, listened to what they had to say, got in touch with senior management and gleaned information from comrades -including making enquiries about colleagues- some of which had attempted to launch similar initiatives -at the Citroën plant in Rennes for example. The interim decision that followed added further momentum to his efforts. The inspector automatically compared the 21 cases submitted to him-19 CGT members and 2 CFTD members- and their work colleagues. He studied age, seniority, qualifications and career paths of over 600 employees and drafted a report stating that union members were automatically paid a salary lower than or equal to the average salary, to the average rate, to the median wage and median rate of their peer group. ${ }^{6} \mathrm{He}$ also observed that militants from other unions were in different situations to the CGT and the CFDT. He therefore observed "an apparent causal link between CGT and CFDT membership and the career development of the people concerned." A report was transmitted to the French Public Prosecutor (Procureur de la République) who nevertheless ruled against taking criminal procedures on 19 November 1997 while at the same time encouraging the union lawyer to do so.

6. The reference group for each union member was composed of employees recruited the same year with the same level of qualification, based on annual lists communicated by the company, thereby enabling a comparison adjusted to each case. (Source: report 6/96, 3 September 1996, direct summons file from the Montbéliard Criminal Court, Appendix I. Tiennot Grumbach collection).

7. M. Zimmermann, work inspector in Montbéliard, Lettre au délégué syndical CGT de Sochaux, 5 September 1996. Tiennot Grumbach collection. 
The lawyer in question, Tiennot Grumbach, a self-professed "workers' lawyer", then suggested bringing direct proceedings before the Criminal Court, in order to prove by a sentence the illegal nature of the discrimination policy carried out by Peugeot, to obtain compensation and finally to expose a breach in the application of union law. In addition, in the same way as delinquents have to go through a probation period, he requested that the company's practices be placed under judiciary review. Assisted by union militants and using the method applied by the work inspector to identify cases of discrimination, he successfully demonstrated these went beyond the scope of those mentioned in the verbatim report. Finally, he added 60 further cases to the original 21. This prompted a direct summons to the Montbéliard Criminal Court. Nineteen members of management and supervisory staff were summoned. However a few days before the court case, the Peugeot management offered to negotiate with the CGT and this was accepted. After discussions between the two delegations as well as union organisations, an agreement was signed on 11 September 1998: this concerned 169 employees, who had acted or were currently acting as official union representatives, or employees who had stood for election. The agreement covered a summary review for each worker as well as back payments spanning twelve years. It also provided for the organisation of yearly coordination reviews with the aim of avoiding potential future discrimination. This way, the company avoided an explicit criminal conviction for its discrimination policy and tried to quash the other procedures underway. These efforts did not however prevent the plaintiffs who initially went to the French Labour Tribunal from launching the total proceedings again in the hope of receiving full compensation and the definitive sentencing of Peugeot for discrimination. This attempt made this time by the lawyer Marie-Laure Dufresne-Castets, did not reach full term either. Before the hearing planned for March 2000, the Peugeot general management negotiated once again and agreed to pay out the total amount, once again avoiding the stigmata of a definitive conviction.

\section{From Solid Evidence to Exemplary Cases of Discrimination...}

These legal proceedings influenced both legal specialists and corporate players because they allowed the plaintiffs to succeed in an area-discrimination towards trade union activity- where up to then, "unfair treatment and the underlying intentions had been particularly difficult to prove -even more so than more direct attempts to limit trade union activity" (VERDIER, 1996, p. 385). In the Montbéliard region, this affair caused quite a stir.

The legal proceedings brought by this small group of Peugeot militants before the Labour Tribunal sought not only to prove unfair treatment but also to prove the underlying discriminatory intention. This latter point was more difficult to identify than discriminatory treatment itself. The first plaintiffs therefore described their career path 
in an effort to prove they had been victims of discrimination. The judge summarized three of the cases heard as follows:

"Mr. Hennequin, tool-and-die maker, states his union activity dates from 1965 and has been an elected member and official union representative since 1967 first for the CFDT then for the CGT; he was recruited on the strength of a CAP [certificat d'aptitude professionnelle, a secondary-level vocational degree] as an unskilled OS2 [ouvrier spécialisé] in 1961; career advancement (promotion) was based on positive results and grades obtained for professional tests taken in-house; after the P1 and P2 tests (P for 'Professional'), he successfully obtained the P3 metal worker test in 1965; 30 years later, he still has the same P3 category whereas his colleagues with the same qualifications and seniority are now TA1 or TA2 [shop technician] and no fault has ever been found with his professional skills.

Mr. Clerc, tool-and-die maker recruited in 1972, stated that he had been an elected member of the CGT since 1977; he obtained P2 grade in 1982 and in 1989 he attempted the P3 in-house training; when the results of this P3 training were announced on 29 March 1990, he had the highest mark and obtained P3, and the baccalauréat $\mathrm{H}$ in 1992; but his requests to be granted ETAM status [employés, techiciens et agents de maîtrise - employees, technicians and supervisory staff] had fallen on deaf ears even despite applying for several positions in this category.

Mr. Martinez, electro-mechanic, skilled toolmaker and P1 C (C stands for qualified) stated that he had been a CGT trade union representative since 1974; that he had started work at Peugeot with a OS2 qualification in 1968, he was given P1 grade in 1971; but since that date he had kept the same qualification whereas workers are automatically appointed P1 to P2 after five years' seniority, which gives access to the P3 test; no objective reason explained why he was blocked in the P1 C category; he was restricted to tasks that did not correspond to his qualifications; that he was never sent on a training course."

Other plaintiffs' ${ }^{9}$ accounts describe similar career paths. The positive results obtained for professional diplomas led them to expect career advancement. Their hopes were dashed as soon as their CGT involvement was made public as of the beginning of the 1970s. By piecing together the different accounts we have a full picture of the system that governed the career of skilled workers. Starting off with the CAP, further grades were awarded based on seniority. To be eligible for a higher grade, a worker had to have worked a minimum amount of time in his/her previous position. At the same time supervisory staff and management produced assessments of professional worth. And examination-type tests called essais provided faster access to a higher grade than seniority. In a certain way, the system combined continuous assessment and ad hoc reviews, assessed by a jury comprising members from different backgrounds, approved

8. Paris Labour Tribunal Council (interim - judge with casting vote), 4 June 1996, « Hennequin et autres contre Société Automobiles Peugeot », in Le Droit ouvrier, no 575, pp. 381-383.

9. Messrs. Aires and Touvenel specifically, who will be mentioned later. 
by management and unions alike. ${ }^{10}$ After describing the assessment system and career development in Peugeot, the judges' decision mentioned that the plaintiffs' career path did not exactly fit this model and pointed out where the management of the workshop had not respected these procedures.

Although these accounts did not constitute real proof, the three pioneers, Jean Vadam, François Clerc and Noël Hennequin attempted by trial and error to produce compelling evidence of these incidents of discrimination: using their professional expertise in industrial design graphics they finally used a visual support to explain the case and this left no doubt in the judges' mind.

"In an effort to justify their claim, the plaintiffs produced comparative tables showing the career development of colleagues with similar qualifications and recruited at the same level, working in the same tool shop, as well as a comparative table showing career development for the staff representatives in the work shop. [...] In addition, the recruitment and seniority criteria for similar levels of qualification of employees made it possible to compare the data in the tables and these were not challenged by Société Automobiles Peugeot." $" 11$

Thus these diagrams, making comparisons based on data common to the workforce as a whole, provided irrefutable proof that seniority was not taken into account for career development of union members, once their union commitment became apparent. The lack of professional competencies argument was also ruled out in the different statements:

"Finally, these are not the only elements produced by the plaintiffs.

Mr. Hennequin has been at the same P3 level for 30 years [...]. The conclusions of the November 1994 interview that he added to the file did not provide for any change, just continuation of the operations that he was already in charge of. The objective assigned to him was to improve his regularity and it is noted that the employee questioned this observation. In addition, this alleged lack of regularity was not supported by any objective argument on the part of the employer and, could not justify the complete lack of promotion over 30 years. Mr. Hennequin produced statements written by his workshop colleagues that confirmed the quality of his work and his professionalism. They also considered that given his level of responsibility, the tasks assigned to him corresponded more to a professional classification in the region of TA2 or TA3.

PSA did not dispute the fact that Mr Hennequin's work had never received negative feedback or disciplinary action." ${ }^{2}$

Not only did this exercise rule out any insinuations about this individual's regularity and, more generally, any possible failure to meet with his obligations as an employee, it also demonstrated his professional worth. Comparison with militants

10. This career guidance policy for blue-collar workers was to be amended later in the 2000s by an in-company reform (MisSET, 2013).

11. Paris Labour Tribunal, 4 June 1996, « Hennequin et autres... », doc. quoted, pp. 381-383.

12. Ibid. 
in other unions mentioned in the files, however eliminated the hypothesis that trade union activity and professional recognition were automatically opposed to each other.

\begin{abstract}
"The comparative table showing the average career progression of union representatives in his workshop drawn up in November 1995 demonstrated the following: CGT representatives -Mr. Hennequin in particular-as well as the CFDT representatives have an average salary lower than that of official representatives from other trade unions. The coefficient and ranking for Mr. Hennequin is P3 HQ [highly qualified] at 225 points and is also inferior to those of the other union representatives despite the former's greater seniority. It is therefore adequately demonstrated that the employer used Mr. Hennequin's union activity to obstruct his career progression and in his case this discrimination was clearly apparent." 13
\end{abstract}

The case of François Clerc mentioned previously typically focuses on his management's refusal to offer him an ETAM position after he obtained his baccalauréat, unlike his other colleagues and despite the intervention of the labour inspector. The trade unionist obtained a compilation of statements from close work colleagues, who without exception pointed out his professional merit and stated their firm belief that this career stagnation was due to his union activity. They also confirmed that they themselves were not union members. These statements are all the more credible because in a certain way they are providing an unexpected counterpoint to the notion of union solidarity. Other cases boiled down to more typical career development interruptions:

"Mr. Martinez has been P1 C for 20 years so, in theory, promotion to P2 level is given after five years if the mark obtained for the P1 test is adequate, which was his case. His statement that he had received no training at the stamping work shop, was not contested. Neither was he contradicted when he stated that there were only four P1 C left in his workshop, all of them CGT union members. Finally, he stated that the tasks that had been assigned to him had borne no relation to his electro-mechanical skills until his superiors acknowledged this in November 1995 -following the intervention of the labour inspector. His colleagues concurred that this could only be explained by his CGT union activities. [...]

PSA explained Mr. Martinez' lack of career development by his failure to pass the P2 professional qualified electrician service technician essai in April 1975, his lack of availability and initiative in his work and lack of trust in his relations with his supervisors. These explanations do not appear sufficiently convincing to justify twenty years of complete stagnation. Discrimination due to his union membership is also blatant in the case of Mr. Martinez.

M. Aires, who worked in the same unit as Mr. Martinez, was also one of the workers with the lowest wage. In the diagram showing the career development of the union activists, he is positioned just above Mr. Martinez. All the CGT members listed in a table have a lower qualification than the other union representatives. Appointed P1 on 1 January 1981, Mr. Aires had to wait fifteen years before being promoted P2 on 12 December 1995 following the first hearing of the Labour Tribunal. Most of

13. Paris Labour Tribunal, 4 June 1996, « Hennequin et autres... », doc. quoted, pp. 381-383. 
his fellow service technicians were P3, P3 HQ, TA1 or TA2. As regards disciplinary matters, examination of Mr. Aire's file shows punctuality-related incidents -which he questioned-in 1985 and 1988. As for his professional skills, he was commended by his employer in 1992 and 1993. Fifteen years without promotion can only be explained by his union membership. In the case of Mr. Aires, discrimination is also apparent.

Mr. Toussenel produced a comparative table showing the career path of union activists in his workshop as at 1 February 1995. It showed that he, the only CGT activist, was at the bottom of the table. Individual diagrams showing the career development for each of the other four work colleagues working in his unit (in a similar job), suggested that Mr. Toussenel, still P3 HQ since 1989, had had a less positive career development and that based on his seniority, he should have been TA1 or TA2. No satisfactory explanation for this lack of promotion has been provided although it should have been granted in 1994. For him too, there was clearly anti-union discrimination." ${ }^{14}$

The approach adopted here by the three militants consisted of taking some outstanding examples, in other words cases that irrefutably highlighted both the existence of discriminatory treatment and its anti-CGT nature. This approach entailed choosing qualified workers with good career prospects and with adequate seniority so as the disparities would show up over time. In addition, a certain number of aspects of factory life likely to cloud the clarity of the demonstration were avoided. This explains why, paradoxically, one of the pioneers of the movement, a victim of both specific and multi-faceted harassment, had his file withdrawn at the initial stage:

"At the beginning of the affair, Jean Vadam was very committed and had demonstrated a lot of creativity, especially when it came to summarising our group discussions using diagrams, during the first phase. [...] He was very gifted, top of his class at the Peugeot Academy. Thirty years on, his designs were held up as examples; he was such an amazing draftsman with exceptional qualities. He took the brevet industriel [professional diploma], he got his diploma before us. He was not a union member at the start, he travelled with his job, he was rather well considered, and he joined the drawing office. And suddenly, he was shunned. Harsh measures were taken against him because he was defiant, not very docile."

(François Clerc, interview with the author, 5 January 2005)

The person involved provided more details of this particular episode:

"At the drawing office they told me to take out a union card, 'the right union card'. And I dragged my feet a little. My superiors harassed me. And one day I refused to take out a membership card for the union they were forcing me to join. I was told, 'you'll remember that.' Until then my reputation had been good.'

(Jean Vadam, interview with the author, 23 May 2006)

14. Paris Labour Tribunal, 4 June 1996, « Hennequin et autres... », doc. quoted, pp. 381-383. 
His co-worker continues:

"They were trying to get him transferred; they stabbed him in the back. I did all I could do to strongly defend him at the time. So we had tricky a case to present because there were so many disputes going on. Above all, Jean was a victim of harassment. The term didn't exist at the time but clearly the bosses were taking it out on him, doing everything they could to make him crack up. And in the end he was excluded from the first legal proceedings."

(François Clerc, interview with the author, 5 January 2005)

Paradoxically, the search for cases of pure discrimination led to the exclusion of other forms of trade union repression.

\section{... To the Exposure of the System}

Even if they were in line with the proceedings brought before Labour Court, relying on evidence that had already proved its worth, criminal proceedings were different in that the number of individual cases examined was increased to $60 .{ }^{15} \mathrm{Most}$

Diagram - Cases Presented during the 1998 Legal Procedure.

Distribution Depending on the Year of Recruitment and Pay Coefficients ${ }^{*}$

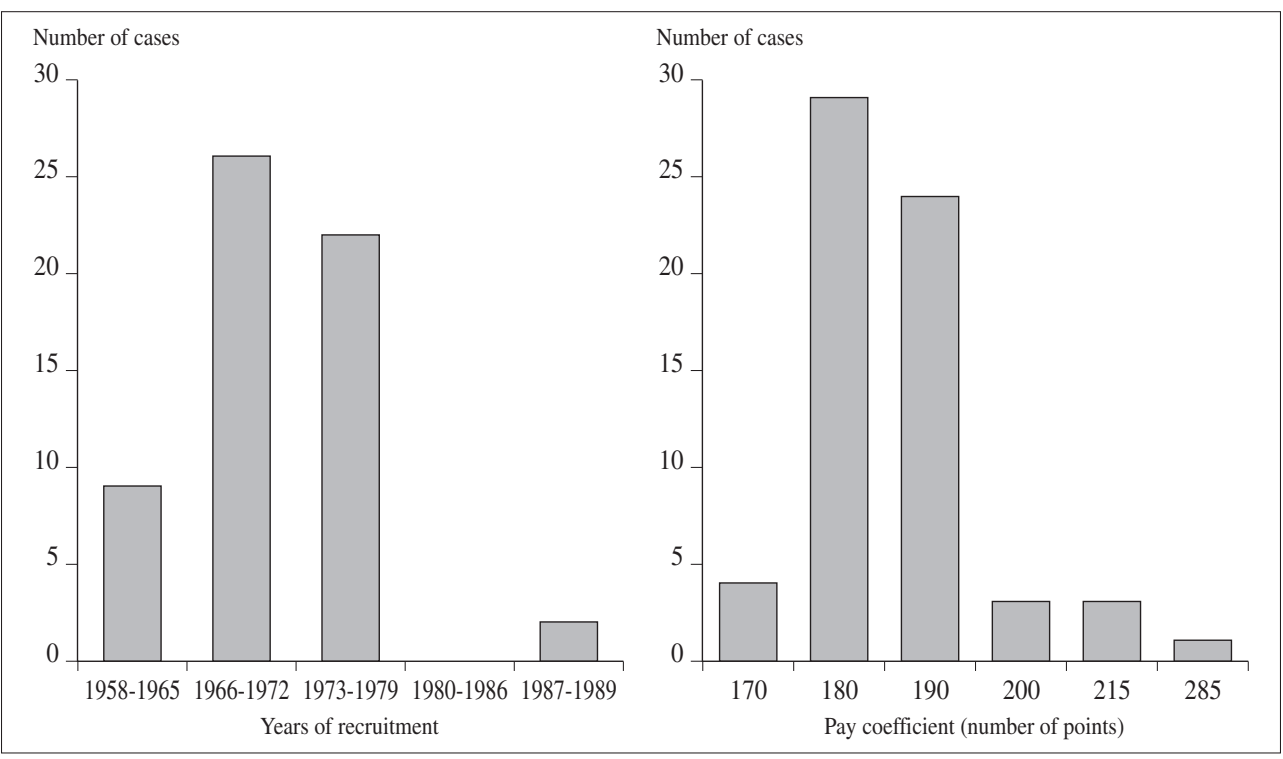

* The lack of workers recruited between 1980 and 1986 corresponds to a period during which the factory practically froze recruitment before starting again (this time on an irregular and on-demand basis) at the end of the 1980s (HATZFELD, 2002).

Source: Automobiles Peugeot, direct quote, Appendix III. Tiennot Grumbach collection.

15. Automobiles Peugeot, direct quote, Appendix III. Tiennot Grumbach collection. 
of the cases presented, in addition to the 20 infringements observed by the inspector, concerned production workers from the mechanical and assembly shops, or from the smelter and paintwork shops. They also included 10 or so female workers which was proportionate to the overall number of women working in the factory, as well as 5 workers born outside France with foreign first names.

Remuneration quotients strongly confirm the existence of intentionally specific treatment (see diagram): only 6 workers are ranked at 200 points or above, 24 at 190 and 29 at 180; 4 are even at 170 points, the minimum required for recruitment at the time of the court case. Almost all the employees had more than 18 years' seniority at the time, which was largely in excess of minimum requirements. And among them the four workers who remained at 170 points had at least 20 years' seniority -a reason to seek an explanation for such a low ranking.

The case file also included brief career summaries based on accounts from individuals, often entitled "Professional and union trajectory". A thorough examination of these documents clearly reflects systemic discrimination.

Many of these accounts contained, in different forms, a "breaking point". For example, one of the plaintiffs described a career path comprising a series of transfers until a strike was declared at the factory: "1981; my union called for a stoppage at the factory, I took part in the movement. 1982: first elected term of office DP-CGT [CGT staff representative]. From that moment on things took a turn for the worse." Other activists also mention the decisive role of the strike:

"It was after the 1989 conflict that I became a real activist with union responsibilities. Elected staff representative in March 1990... From that date I had no individual salary increase (arbitrary bonus), no promotion, no change in grade."

The discriminatory approach was sometimes more explicit:

"1989 was the year that marked a complete breaking point. Playing a very active role in conflict, a card-carrying CGT member... from then on, I had no individual raise. When I requested an explanation for this situation, the foreman didn't hesitate to reply that it was because of my union activities and positions. I accepted a term of office as a CGT elected member."

A strike was sometimes enough to trigger off a negative reaction. Therefore a worker who had moved quickly up the career ladder, 20 points in two years, took part in a stoppage in his sector: "Following this stoppage, the foreman summoned me and issued an ultimatum -either I accepted the transfer or I would be fired for incompetence."

However other accounts failed to mention impact of the strike. Simply becoming an activist was enough and had similar consequences:

"I was elected union representative in 1982. Since that date my career advancement has come to complete halt. Nothing -no promotion, no arbitrary bonus. This leads to one conclusion. My involvement in the CGT trade union sabotaged my career." 
Another added the following:

"In December 1996, I stood for staff representative. When my supervisors found out they didn't approve and started to make things difficult for me. In December, I was suspended for a day, supposedly for a drop in production rate; after doing some research it turned out that there were no grounds for this."

Some reports mention trigger factors that were more tenuous: "The staff engineer requested that I be taken off the assembly line with a view to becoming team leader. But there I openly expressed my opinions, I joined a union and that was the end of my career." A work incident could have the same effect: "After a difference of opinion with my boss about the incorrect positioning of a car I was working on, I asked the CGT representative to intervene and since then, no more promotion." And in certain cases, close contact with the union simply seemed to be the problem:

"In 1980, my mark for the DIPO (nowadays known as "career interview"16), my mark for the section entitled "state of mind and attitude towards the company" was $2 / 5$. As I was surprised it was so low, my contact told me straight out that it was because every morning I shook hands with the CGT representative."

Another account is of a similar nature:

"Just to recall my last career interview with Mr. B., sector manager, who had stated this objective beforehand: 'Your increase in points.' [He told me]: 'Your work is satisfactory, you don't come in late, you don't take sick leave. I would really like to promote you but you are CGT and as well as that you are always with the union representative. So if you really want a promotion you would have to at least stop seeing this union representative."

According to certain accounts, supervisors appeared to be uncomfortable with this situation: "So when I asked the question about my sluggish career advancement he seemed embarrassed and replied: 'You know why."' Yet another employee stated:

"I recently remarked to my boss that 19 years without promotion and no cause for criticism was a bit long; he merely answered: 'Yes, it's a bit long.' I interpreted that as an admission of powerlessness to solve the problem at his level."

Sometimes the pressure went no further. Some of the statements clearly intended to emphasise the contrast between anti-union harassment and the recognition these union members received from their supervisory staff concerning the quality of the work. One of them also remarked: "No criticism concerning my work, on the contrary -I received congratulations as the letter of 24/6/88 confirms." Another noted:

"Of course I have never received any criticism as to the quality of my work. During interviews with my managers, they agreed without exception that I am a good team member. Like my other colleagues, I take training courses as part of my career

16. The acronym stands for both the individual staff file and the interview between the employee and his/her direct superior, who deals with the annual production of the document (cf. infra). 
advancement but unlike them, who have received formal recognition, I'm still stuck at P3 215 points."

Another underpaid worker pointed out his own energy and drive:

"I've never had any complaints about the quality of my work. Indeed this would be difficult because I'm very interested in my job and the work I do; all the suggestions that I have made to up to now are a reflection of this. Of course, I always got the corresponding bonus, $[\ldots]$ the managers who decided to give it to me also congratulated me and encouraged me to keep up the good work."

This contrast could also be formulated more succinctly: "At work I have never received a single complaint, my sector manager told me that I was a good element but that I had a twisted mind." In some cases the activists pointed out the contrast between this professional stagnation and their responsibilities: "[apart from my union terms of office] I also act as administrator for the company health insurance scheme and the retirement fund." A similar statement came from a female activist elected to sit on the Labour Court Council: "I have done many training courses outside the company, for example leading meetings, writing up the minutes. I specialised in labour law. This knowledge has never been recognized by the company."

In another part of the case files, the trade unionists described attacks going beyond classification and remuneration. They could be directed against the union activity itself: "The sanctions I receive are always linked to my union activities, overtime, handing out tracts, and so on." Or they could sometimes have consequences on the personal life of employees:

"I've been put under a lot of pressure, refusal of a building loan in 1976 on the grounds of my CGT membership, which is what my management explained at the time; and refusal to promote me: 'We would rather offer promotion to an incompetent worker than give it to a commie'; a suggestion was made by my management that I join the SIAP [Syndicat indépendant des Automobiles Peugeot, management-oriented]."

Above all, the work itself was targeted, for example production:

"I receive 'special treatment" ${ }^{17}$ as far as my workload is concerned. My superiors accuse me of 'lack of activity' every week. So now in order to justify my 'overtime', I keep a trace of all the tasks that I carry out. Then I wrote to the management of the workshop and copied in the work inspector on the grounds of harassment, difficult to put up with, that I am subjected to."

Another worker stated:

"Fourteen years in the same position, repeating the same gestures over and over resulted in Epicondylitis (a recognised occupational disease) on the left elbow. It was painfully difficult to hold on to my job. My management did not make any great

17. The fragments in italics, or underlined, are a reproduction of the original documents. 
effort to find a solution to my problem. The only solution they found was to sanction me on four occasions, by interim suspensions with immediate effect."

A female worker also stated:

"Mr. T who was my foreman at the time, clearly told me that it was my union involvement that was an obstacle to both my career advancement and that of my husband. Taking advantage of a reorganisation scheme, they put me [sic] into production. I took up my first CHSCT (Comité d'hygiène, de sécurité et des conditions de travail - safety and hygiene committee) term of office in 1981, I was also a CFDT member, I was then elected as shop steward for the CGT until 1992, with all the bullying that goes with the role of militant. Following an occupational disease (Carpal Tunnel syndrome) in 1994, management took advantage of this to demote me to packaging. And after the classification agreement that I had requested myself, they had the cheek to grant me 190 points with no increase in wages. The case is currently before the Labour Tribunal."

Another case was described with a touch of humour:

"Anecdote: for five years I held a position which was estimated to be equivalent to 200 points and my work was fully satisfactory. When I actually requested those 200 points, this being justified because I was already in the job... all they could manage to do was to put me in a workplace at 190 points."

The systemic nature of this discriminatory approach did not exclude varying attitudes at local level, more specifically when it came to close hierarchical relationships. Direct managers sometimes could adopt either an ambiguous or a sympathetic approach as we have seen above. The following case confirms this:

"Mr. M., technician, responsible for this zone, offered me the position of assembler in his department. He did however express one reservation: 'I had to commit to stop everything', in other words, drop the CFDT. When I refused to agree to such a compromise, Mr. M. congratulated me for my exemplary courage."

Conversely, some supervisors were even more intransigent than senior management:

"Following the 89 conflict, the results of the negotiations in December 1990 had a positive impact on my minimum rate. My supervisor at the time called me into his office to announce my new fixed rate with the following reaction: 'It is my duty to inform you of your change of rate (Fr. 220) but because I do not agree with this bonus, once I have read it out I will tear it up.'”

Differences in attitude were reflected by a policy of transferring activists and moving trade unionists from one sector to another -a policy qualified by certain

18. Other accounts mention pay freezes despite promotion. This would point to the fact that each coefficient does not correspond to a strict index point, but rather an indicative area within which management can decide, in parallel with general pay rises. 
plaintiffs by the understatement "sanction-transfer". These differences could also govern the scope of discrimination. This could be sometimes described as definitive:

"Two years ago, when I had already stopped all union activity, my boss admitted during an interview: 'Your work is good but your trade union past will stay with you forever...' It was up to me to get the message..."

However, for a majority of cases, stopping discrimination was subject to conditions:

"I never got the same promotions as my work colleagues; on the other hand, my boss told me on several occasions that he had nothing personal against me but he gave me to understand that I had to stop the CGT if I wanted to get promotion."

Other examples:

"I never hide my ideas, and in fact I am a CGT shop steward and CHSCT representative for the foundry section. This is why my career has not moved forward. On the other hand, my bosses have clearly stated that if I change direction, everything could be possible."

This requirement is sometimes met:

"As of the beginning of the 1980s and until 1990, I held a term of office for the CHSCT. During this period I never got a pay rise [...]. And it was only when I was no longer a member that they granted me a small increase in wages as a gesture of thanks."

Along with the differences highlighted in the personal experiences documented in this compilation of testimonies, some rare passages show an overall strategy, as evidenced in the following excerpt:

"Now that my activist days are over, I can say that I paid a high price for my trade union activities -from a financial point of view, of course- but also the indignation, the frustration because my skills were never acknowledged. The Peugeot system is designed to break the spirit of those who hold their heads high."

However, these accounts do reflect union members' unyielding loyalty to their initial commitment: "Since 1989, I have been regularly elected as deputy staff representative. Of course there is a price to pay for this but I'm one of those who choose to accept this with dignity." When reading these documents, we are struck by the unwavering determination to stick to the choices made and the will to reveal the harmful effects of this system. The account below starts by documenting the circumstances that led to union membership and then lashes out at the perverse nature of the system:

"Back then when I was a fitter-turner, during my first 'DIPO' interview, Mr. T., the workshop supervisor, made sure I understood that if I wanted to demonstrate my commitment to the company, I needed to join a 'reformist' union. When the interview was over I asked Mr. D. [CFDT staff representative] to put me on the list of future representatives. [...] I was discriminated against for having union sympathies, for being a member and activist for those trades that are rejected by the different 
management teams of Automobiles Peugeot. If I hadn't reacted that way today I would most likely be unemployed or seriously ill. Eighteen years without any change of grade, only activists dedicated to a common cause can put up with that."

The 60 accounts, briefly reviewed here, make up only one part of the case file compiled by the union's lawyer, which also includes the systematic comparisons and other pieces of evidence compiled in the working model provided by the labour inspector when putting his report together. The sum of these elements show that the scope of this phenomenon extended much further than the shop floor and skilled workers; in fact, it spanned all manufacturing sectors, which made up the greater part of the plant. The shift from specific model examples to a general representative approach carried all the more weight because the company and its representatives did not offer factual evidence when providing a defence to the case file and the proceedings that followed. As we have seen, Peugeot chose to negotiate, which was a total turnaround in their usual approach to these matters.

\section{The Dismantling of a Repressive Approach}

The decisions of the Labour Tribunal and the agreements reached had profound implications for the company in the Montbéliard region, for both professionals in the legal field and all players involved in professional relations. This refers to the traditional hostile approach to the CGT and the CFDT at Peugeot and, certainly in a different way, the car-manufacturing sector. These traditional approaches correspond to union-specific strategies implemented by companies belonging to the PSA group between 1974 and 1978.

Among the leading carmakers that emerged in France after the Second World War, Simca adopted an industrial relations model of a corporatist type. This model comprised systemic action against union activity, targeting the very existence of union organisations representing employees, the development of a package of social benefits intended to maintain a spirit of loyalty towards the company (an extension of industrial paternalism) and the setting up of "home-grown trade unions" bringing together all grades and categories of employees. A key feature of this model was the considerable place given to personnel management and the delegation of social actions to so-called apolitical unions (Confédération française du travail [CFT] - French Confederation of Labour, and then the Confédération des syndicats libres [CSL] - Independent Trade Union Confederation). This also included repressive measures aimed at eradicating CGT and CFDT trade union activities in different ways, sometimes violent, some of them illegal (Loubet, HatzFELD, 2001; 2002). Citroën also adopted this corporatist model, in a series of different stages between 1960 and 1970.

Peugeot did not follow exactly the same path. Although still under the influence of regional paternalism, the company nevertheless adapted to the new conditions of 
industrial relations that marked the post-war period (HATZFELD, 2002). The CGT, which had the majority workers' vote, offered employees an alternative to corporate supremacy. During the 1960s, a series of strikes was called to protest about working conditions resulting from streamlining production processes and changes to industrial relations. The disputes focused on what was later to become known as the "Fordian compromise" even before it existed. New forms of strike action emerged, while sacking of trade union members resulted in mounting social tension. Changes within the CFDT, which started to compete with the CGT, reflect this period (HATZFELD, 2002). In May-June 1968, the PSA Sochaux plant, which was the industrial centre of the company, went on strike for a month and occupied the premises. This was complex and will be remembered as a day of bloody and traumatising violence on 11 June. The outcome, seen as a semi-defeat by PSA management, led to a change in social policy.

Under the leadership of General Feuvrier, who had formerly headed up the antiOAS campaign (Organisation de l'armée secrète - Secret Army Organisation) during the Algerian War of Independence in 1961-1962 and was given the role of centralising the company's personnel management, new policy directions were introduced, with varying degrees of success. One immediate area of intervention consisted of bringing in henchmen from a special temporary employment agency. These individuals used targeted violence against militants inside and outside the plant before being fired due to involvement in common law offences (ANGELI, BRIMO, 1975; HATZFELD, 2002; LOUBET, 2009). As an experiment, and based on practices at the time used by ChryslerFrance or Citroën, the personnel management division created a workshop counsellor position, intended to replace employee-elected representatives. But this did not work and the unions stood their ground while management did not support this attempt. Another effort was made to force the managerial and supervisory staff who were CFDT members and held the majority until 1968 in the collège (Trade Union representative body) to step down. The aim was to make room for the newly-formed Confédération générale des cadres (General Confederation of Executives - CGC). The CFDT members discreetly called upon François Ceyrac, both head of the Conseil national du patronat français (National Council of French Employers - CNPF) and company director, and nipped the manoeuvre in the bud..$^{19}$ This form of resistance, at times open, at times tacit, succeeded in preventing Peugeot from adopting the corporatist model. This meant that a form of trade union pluralism could continue to operate openly in the workshops. The impact of the PSA acquisitions of Citroën in 1974 and Simca in 1978 was therefore limited. For some years to come, the two new subsidiaries would attempt to retain their specific identity as opposed to promoting their system, which in any case was challenged by the 1982-1984 strikes at the Aulnay and Poissy sites (GAY, 2014; 2016).

19. Jean-Marie Philippe, Henri Desloges, interviews with the author, in 1983, then 2004. Engineers at Peugeot-Sochaux and active Catholics, both at the time were leaders of the Syndicat national des ingénieurs et cadres affiliés à la CFDT (National Union of Engineers and Managers affiliated to the CFDT). 
Despite these limits, a fresh strategy was implemented in Sochaux from 1973 onwards. It entailed combining a policy of oppression directed at the most active trade union members and militants and measures consisting of classifying and ranking all the employees based on their attitude towards the company.

The principle of such a methodical ranking system was communicated in stages within the Peugeot plant. An individual staff evaluation process in use since the 1960s consolidated this. Managers therefore ranked their employees using a grading system. These concerned work and behaviour and were not backed up by any type of grid, etc. (GUIGO, 1994). In response to accusations of arbitrary assessment methods, management responded by drawing up a marking grid to be used by supervisory staff and personnel managers. However, this grading system was confidential and was not transmitted to the people involved. Furthermore, it was challenged by the unions. In 1976 the grid was improved and once again the CGT opposed it on the grounds that criteria concerning the "state of mind" vis-à-vis the company should be removed. In 1978, the document was redesigned as an individual file for workers (DIPO), supposed to help manage workers' personal careers. Despite denial by company management, the suspicions of the trade unionists concerning this individualised ranking was not unjustified; it was indeed by using the data in these files that differentiated statistics were drawn up concerning attitudes towards the company. In an internal company document the statistics were commented on as follows:

"We can see the importance of the individual staff file known as the DIP [dossier individuel du personnel - Employee's Personnel File] in the vast array of resources available to improve the social climate. In particular, it will help us to know why certain (employees) are disappointed or frustrated and to help them adopt a more positive attitude whenever possible. ${ }^{20}$

At the same time as this gradual ranking process intended to cover the full workforce was implemented, the company undertook to redesign the union landscape to its own taste. Thus management encouraged trade unions qualified as reformists, or encouraged their creation; as of 1970, the CFDT entered the scene (FAVRE, 1998), and the Confédération française des travailleurs chrétiens (French Confederation of Christian Workers - CFTC) re-emerged some time later. Force Ouvrière (Workers' Power - FO) was put under particular scrutiny by management, especially after 1976. For critical categories such as skilled workers, supervisors and line managers, managerial pressure mounted and intensified in an effort to get them to join these trade unions. At this time, Peugeot consolidated its discriminatory practices and bolstered its discriminatory methods by systemising them into an anti-CGT and CFDT policy, as these two trade unions were qualified as "revolutionary" by management. Humiliating transfers, procedural harassment, warnings, suspensions and pay deductions were a

20. Internal document at Peugeot-Vesoul published in a section belonging to a supplement to CFDT Métaux, no 12/A, December 1981, p. 50 (direct summons file from the Montbéliard Criminal Court, September 1998, appendix IV. Tiennot Grumbach collection). 
regular occurrence for the union militants (Minazzi, 1978; Corouge, PialouX, 1984, 1985, 2011). Some of these adopted an intransigent stance and refused to leave the company, leading the situation to deteriorate and develop into harassment, humiliating and generally harrowing for the victims and at times involving supervisory staff and management's participation. These tactics, affecting the CGT and CFDT members to lesser or greater extents, reached a tragic crescendo when Philippe Marchau, a CGT activist and Trotskyist, received 72 sanctions between May 1977 and November 1979. These included a number of days of suspension and pay deductions and led him to commit suicide on 8 February 1980 (Goux, 1986). ${ }^{21}$ This tragic event, and the controversies surrounding it, are engraved in the memories of the Sochaux site, all the more so as this was not an isolated incident.

The events of 1981 hampered this wave of repression. Some months after the left came to power, a strike was called at the Sochaux site in autumn 1981. This was partly to protest against infringement of union freedom and rights, thereby releasing the stranglehold in which the union dissidents operated (Corouge, Pialoux, 2011). In November 1981, the metallurgy branch of the CFDT launched a campaign condemning Peugeot's strategy and accused the company of "carrying out anti-union discrimination." 22 Producing a series of confidential documents for internal management and supervisory staff, it revealed a deliberate strategy (box).

\section{Box}

\section{Categorising Staff -All the Better to Discriminate against Them?}

These documents were compiled by the metallurgy branch of the CFDT and show that the workforce was classified on a scale representing two extremes -on the one hand the company, backed up by pro-corporate alliances and on the other the CGT and CFDT (qualified as revolutionary).

Based on these opposing criteria, several documents sort the personnel into different behavioural groups. ' One of these, entitled "Methods for Preventing Conflict", describes several strategies: "Recruitment, welcome and induction procedures: mark out your territory; outstrip the adversary, put reformists before revolutionaries." It ranks company employees according to their level of loyalty to the company. Seven criteria are listed: committed (pro-company), ally, favourable, neutral, distrustful, opponent and finally irreconcilable. For each of these, there are four columns: the first describes the behaviour

1. Documents 1, 2 and 6, from a supplement to CFDT Métaux, no 12/A, doc. quoted.

\footnotetext{
21. The criminal case file mentioned above bears other names of militants, who have been associated with comments such as "suicide attempt" or "tragic end" for failure to "put up with constant oppression".

22. « Durcissement de la tension sociale chez Peugeot », Le Monde, Wednesday 11 November 1981.
} 
whereas the second was used to identify the motivating factors (common agenda / intentions / assumption / personal agenda, etc.). The following intends to define the "predictable outcome from the associate", in other words what management can expect from him/her: the scale of prospects includes total and permanent commitment, partial compromise and permanently challenged compromise, abstention or opportunist reaction, weak opposition in general with the occasional tacit compromise, total and permanent hostility, etc. The last column, bearing the title "Symbol" contains simple signs such as a cross or a circle easily drawn with a pen or pencil or even arithmetic values ranging from 4 to -4 . It explains the practical purpose of the table, clearly intended to guide supervisory staff in systematic staff grading exercises.

Another leaflet describes the same procedures in its section entitled "Employee Strategy", to wich was added a section entitled "Results Obtained, Conclusion". It describes in detail the method used on one of the company sites and which consisted of reducing the influence of the "adversary", namely the CGT (the CFDT being practically absent) and the method used. It also describes "the men responsible for implementing this action" - who happened to be FO union members- and finally its overall effectiveness, as the site in question now boasted "a 'follower' workforce, working in the interest of the company's welfare."

This same ranking exercise can be found in documents used at three different Peugeot sites. One of the documents published the statistics drawn from a breakdown of employees into six groups: fully satisfied, satisfied, indifferent, disappointed, frustrated and finally against.

At the same time, some members of the National Assembly suggested creating an enquiry commission into staff policy at Peugeot. ${ }^{23}$ In addition to these events the CGT and the CFDT contacted the labour inspection, as mentioned above, about some cases of union discrimination.

These initiatives threw a spanner in the works when it came to management's strategy in terms of industrial relations. However, discriminatory practices were not completely eliminated. Discrimination continued to exist during the 1980 s and 1990s, along with a policy of human resource management based on the vision of the company as an area of conflicting influences. In fact, management stayed the course until the 1990s. And this was duly confirmed during a business seminar where the HR manager of the group stated ${ }^{24}$ : "Trade unions as such do not have spokespersons (the spokesperson for the personnel is its direct superior and that is that)."

As time went by, shop floor relations tended to be more complex and changeable than those prescribed by management. They reflected a policy of ranking and discrimination of employees based on a presumed opposition between the objectives of the

23. Appendix to the report of the hearing on 15 October 1981 (direct summons file before the Criminal Court, September 1998, appendix IV. Tiennot Grumbach collection).

24. Nathan-Hudson J.-M. (1989), «La politique des ressources humaines PSA », Séminaire DPT 30-31 mai 1989, EDT DPTNHU-03, pp. 86-97. Tiennot Grumbach collection. This document was at the time a subject of public controversy. 
company and those of their presumed adversaries, namely the CGT and the CFDT. The discrimination in the strict sense of the term suffered by the militants reflected the efficiency of a gradually automated system. An approach initially used in situations of open conflict was subsequently shaped into repressive measures to be applied to everyday working life. ${ }^{25}$ In addition, the individuals involved in the life of the factory had got used to witnessing discrimination based on open allegiance (or otherwise) to the company. It was this succession of events and action that morphed into system that was partially dismantled by the Sochaux-based CGT militants' legal proceedings at the end of the 1990s.

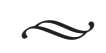

What did the legal proceedings and the subsequent Peugeot agreements change at the turn of the 1990s? If by choosing to negotiate, the company management avoided the stigmata of the Cour de Cassation sentence, it clearly lost its battle of wills with the three trade unionists who launched the procedure with quick support from the Sochaux CGT. In fact, these events and their outcome altered a certain number of parameters governing industrial relations within the company.

As far as the industrial organisation of the company was concerned, the legal process and the subsequent introduction of joint monitoring schemes hampered systematic discrimination. When Jean-Martin Folz took over from CEO (Chief Executive Officer) Jacques Calvet in October 1997, this made changes easier. To this we can add the exodus of a generation of managers marked by the tensions of the 1960s and 1970s and the priority their successors gave to increasingly industrial and managementfocused issues, while the company sought to develop a strategy adapted to a more uncertain climate. In addition, industrial reorganisation saw an outsourcing of activities to local car part makers and a reduction in the workforce, which was now dedicated to tasks entailing the core activity of the plant. Turnover decreased, partly perceived by the management as a costly phenomenon but nevertheless an accepted means of "elimination of the embittered elements" (HATZFELD, 2002, p. 393).With the development of a new form of collaborative management, the context was less and less conducive to reining in employees. This new context discredited confrontation with unions as far as management and supervisory staff were concerned.

For trade unions and the workers that supported them, the battle against discrimination and its successful outcome rang in certain changes of direction in union action. This occurred at a time when hopes of potential social change that emerged at the beginning of the 20th century and were reshaped following the resistance movement in the 1970s had started to fade (VIGNA, 2012), a decline exemplified by a certain disenchantment following initial optimism generated by the left-wing government election in the early 1980s. This change of direction and activity led trade unions to

25. Quoted from Nathan-Hudson J.-M. (1989), « La politique des ressources humaines PSA ». 
redirect their struggle and focus on their employers' harsh repression of trade unionism. Repressive measures were considered by the unions not so much as a means of consolidating class awareness and preparing the workers for future class struggles; but more from a labour legislation standpoint and the right to protect trade unionists in their capacity as workers. A similar direction was taken in the mining sector of the 1970s, which brought judicial-labour movement relations into play (FONTAINE, 2014). At the Peugeot-Sochaux plant, some activists re-examined their personal prospects in the light of this change of context and some of them even considered that their union activity enhanced their professional status. The professional training courses they chose reflected, partially at least, a renewed interest in their professional activity, qualifications, training and careers. This change could not leave the workforce organisation unscathed ${ }^{26}$. The issues at stake in conflict were in fact viewed differently by the factory workers and, more generally, by all the employees. For skilled workers holding diplomas recognised in the industrial sector, their sights are set on a factory career. This is not the case for most unskilled workers, whatever their title may be. Unless they have specific professional qualities, career advancement opportunities are slim, except if they move to another professional category as a minority has always done. For them, working conditions serve as a reference in their fight against discrimination, at least as much as or more than their careers themselves. Discussions among members of the Sochaux union reflect diverging awareness and prospects between these two extremes of the working world. The activists concerned had to choose between highlighting typical cases and presenting collective union action. They also had to choose between equal distribution of the sums received or proportionate compensation for any career disruption suffered. The tactics used for the above served to reconsolidate union activity and to create worker solidarity; issues such as work and job equality, solidarity and justice were once again brought to the fore. This enabled them to reconnect with previous controversies within the working environment itself.

\section{REFERENCES:}

Angel, C., Brimo, N. (1975). Une milice patronale, Peugeot. Paris: F. Maspero.

Beaud, S., Pialoux, M. (1999). Retour sur la condition ouvrière. Enquête aux usines Peugeot de Sochaux-Montbéliard. Paris: Fayard.

CHAPPE, V.-A. (2013). « Dénoncer en justice les discriminations syndicales : contribution à une sociologie des appuis conventionnels de l'action judiciaire. » Sociologie du travail, 55(3), 302-321.

CLERC, F. (2004). « Discrimination syndicale : la stratégie de la CGT. » Semaine sociale Lamy, 1190, 6-13.

26. The notion comes from Stéphane BEAUd and Michel Pialoux (1999). 
Corouge, C., Pialoux, C. $(1984,1985)$. «Chronique Peugeot. » Actes de la recherche en sciences sociales, 52-53, 54, 57, 60.

Corouge, C., Pialoux, C. (2011). Résister à la chaîne. Dialogue entre un ouvrier de Peugeot et un sociologue. Marseille: Agone.

FAVRe, D. (1998). Ni rouges ni jaunes. De la CGSI à la CSL. L'expérience du syndicalisme indépendant. Courbevoie: Midi moins le quart.

Fontaine, M. (2014). Fin d'un monde ouvrier. Liévin, 1974. Paris: Éditions de l'École des hautes études en sciences sociales.

GAY, V. (2014). « Lutter pour partir ou pour rester ? Licenciements et aide au retour des travailleurs immigrés dans le conflit Talbot, 1983-1984. » Travail et Emploi, 137, 37-50.

GAY, V. (2016). Immigration, conflits sociaux et restructurations industrielles. Les ouvriers de Citroën et Talbot au début des années 1980. (Thèse d'histoire, université d'Évry).

Guigo, D. (1994). Ethnologie des hommes, des usines et des bureaux. Paris: L'Harmattan.

Goux, J.-P. (1986). Mémoires de l'Enclave. Paris: Mazarine.

HatzFeld, N. (2002). Les Gens d'usine. 50 ans d'histoire à Peugeot-Sochaux. Paris: Éditions de l'Atelier, Éditions ouvrières.

HATZFELD, N. (2014). « Lutte contre la discrimination syndicale à Peugeot-Sochaux : combats judiciaires et mutations syndicales (1995-2000). » In A. Narritsens, M. Pigenet (Eds.), Pratiques syndicales du droit. France, XX ${ }^{e}-X X I^{e}$ siècles (pp. 255-264). Rennes: Presses universitaires de Rennes.

Loubet, J.-L. (2009). La Maison Peugeot. Paris: Perrin.

Loubet, J.-L., HATzFeld, N. (2001). Les 7 vies de Poissy. Une aventure industrielle. BoulogneBillancourt: ETAI.

Loubet, J.-L., HatzFeld, N. (2002). « Poissy : de la CGT à la CFT. Histoire d'une usine atypique. »Vingtième Siècle. Revue d'histoire, 73, 67-81.

MinAZZI, G. (1978). En marche. 30 ans de lutte à Peugeot-Sochaux, l'itinéraire d'un militant. Paris: Syros.

Misset, S. (2013). « Classifications ouvrières et confrontation de générations d'ouvriers qualifiés : vers une remise en cause de l'ordre de l'ancienneté ? » Sociétés contemporaines, 90, 29-52.

VERDIER, J.-M (1996). « Note sur le jugement des Prud'hommes du 4 juin 1996. » Le Droit ouvrier, 575, September, 383-385.

Vigna, X. (2012). Histoire des ouvriers en France au XX ${ }^{e}$ siècle. Paris: Perrin. 